\title{
EFFECTS OF AUDIT AND NON-AUDIT SERVICES FEES ON CORPORATE PERFORMANCE OF FIRMS LISTED IN PAKISTAN
}

\author{
Muhammad Naeem Khan ${ }^{1}$, Adnan Ahmad ${ }^{2 *}$, Muhammad Asad Khan ${ }^{3}$, Aziz Javed ${ }^{4}$, Zia ur Rehman ${ }^{5}$ \\ ${ }^{1}$ MS, Scholar, Institute of Business Studies and Leadership (IBL), Abdul Wali Khan University, Mardan, Pakistan; \\ ${ }^{2 *}$ Associate Professor, Institute of Business Studies and Leadership (IBL), Abdul Wali Khan University, Mardan, \\ Pakistan; ${ }^{3}$ Assistant Professor, National University of Modern Languages, Islamabad, Pakistan; ${ }^{4}$ Assistant Professor, \\ IBA, Gomal University, DI Khan, Pakistan; ${ }^{5}$ Elementary Teacher, KP Worker Welfare Board, Peshawar, Pakistan. \\ Email: "adnankhattak@awkum.edu.pk
}

Article History: Received on $22^{\text {nd }}$ May 2021, Revised on $1^{\text {st }}$ June 2021, Published on $9^{\text {th }}$ June 2021

\begin{abstract}
Purpose of the Study: The main purpose of this study is to examine the effects of the provision of audit and non-audit services jointly by the same audit firm on the corporate performance of firms in the capital market of Pakistan.

Methodology: This study uses hand-collected secondary data taken from firms' financial statements, the Pakistan Stock Exchange (PSX), the State Bank of Pakistan (SBP) for 2012-2016. Panel data analysis techniques are employed using Eviews statistical software.

Main Findings: we find a negative relation between audit and non-audit services fees with the firm performance. It is also documented that the appropriate amount of the NAS fee exceeds the amount of the audit fee received by the same auditor in the same assignment.
\end{abstract}

Application of the Study: This study has vital implications from both theoretical as well as practical perspectives. It adds a significant aspect of audit and non-audit services provided in the context of Pakistan to the existing body of knowledge/literature. This study also implies the bifurcation of audit services provision and its serious implications on the corporate sector of Pakistan. These results thus, signify its implications for regulators as well as standard setters in Pakistan.

Novelty/Originality of this Study: Various studies covering the audit aspect have been conducted in Pakistan. However, this is a unique study covering the multi-facet dimensions of audit, i.e., audit and non-audit services provision by the same audit firm and its effects/implications on corporate performance in Pakistan.

Keywords: Audit Quality, Audit Fees, Non Audit Services, Top 4 Auditors, Firm Performance, Accounting \& Auditing.

\section{INTRODUCTION}

Major accounting and auditing failures in the last decades and during the Global Financial Crisis of 2008 again highlighted the importance of quality financial reporting (Mendonce \& Persson, 2014). The effects of these scandals captured the attention of regulators toward the quality of financial information. Among the major facets of quality financial information is reducing information asymmetry (IA) between investors and managers. Ullah, Malik, Zeb, Rehman (2019) concluded that the quality of such financial information increases with a decrease in information asymmetry. However, such higher IA leads to manipulation in the reported earnings. Moreover, investors' reliance on market information than firm fundamental information (FFI) also leads to management's decisions that may expropriate investors' funds.

Prior literature emphasizes reducing IA through voluntary and mandatory disclosure and regulation of financial information. Frankel and $\mathrm{Li}$ (2004) argue that regulators, standard setters, auditors, and other capital market intermediaries enhance the reliability of disclosure utilizing the application of accounting standards, the rule of law, stock exchange listing rules, etc. (Sufy, Almbaideen, Abaadi \& Makhlouf, 2013; Paulo, Girao, Carter \& Sousa, 2013). Similarly, earlier literature on international accounting reports the importance of such disclosure and regulatory regimes and their economic consequences. This emphasis leads to enacting rules, including Regulation Fair Disclosure and the renowned Sarbanes Oxley Act (SOX). The disclosure also represents the level of compliance set by accounting standards in the said premise as indicated in the literature. Frankel and Li (2004) describe the importance of IFRS from the perspective of disclosure, i.e., clarity, comparability, and understanding by non-financial users and fair valuation.

Prior research indicates a strong relationship between financial reporting and auditing (Hribar et al., 2014). Zhou and Elder (2003) report that auditing being another investor protection (IP) oriented mechanism, results in providing reliable and quality financial information. Literature highlights variation in audit fees to indicate fluctuations of firms' performance and financing at a higher cost of capital in the future (Stanley, 2011; Hope et al., 2009). Results also show a positive association of audit fees with the companies facing negative stock price shocks (Hackenbrack et al., 2014). Agency cost is also a viable tool for creating demand for high-quality audits.

Auditing can be defined from two different aspects internal ii) external audit. Internal audit is defined as:

"An independent, objective assurance and consulting activity designed to add value and improve and organizations' operations. It helps an organization accomplish its objective by bringing a systematic, disciplined approach to evaluate 
and improve the effectiveness of risk management, control and governance processes" (Stewart, Jenny, Subramaniam, Nava, 2010).

External auditing can be defined as: "An examination of financial statements by an independent accountant under generally accepted auditing standards, as may be supplemented by the Commission, to express an opinion thereon" (ISA 11: O' Connor, 2002).

External auditor's dependence on the efforts of internal audit functions has been the focus of researches for more than three decades. Outsourcing of internal audits has grown extensively with such services performed by a specialist and the prevalent traditional accounting firms (Munro \& Stewart, 2009. Thus, external auditors' decisions influencing the work of internal auditing in the premise of financial statement auditing helps in improving not only the disclosure aspect but also the quality of the audit being performed.

Earlier literature, using audit fees as a proxy, believes that fees being paid to the auditor affect the auditor's performance (Hoitash et al., 2007). Hackenbrack et al., (2014) describe audit pricing as an associated cost of providing audit services demanded by the client. The audit fee is thus comprised of fee for the efforts implied on the expression of an audit opinion on the fairness of the financial position, operations, and the cash flows in adherence to the accounting standards (Auditing Standard No. 1), the efforts in the form of provision of consulting services and the designated non-audit services (NAS) (Santos, Cerqueira \& Brandao. 2015).

Gramling and Vandervelde (2006) demonstrate the biasness of external auditor opinion regarding the internal audit quality when other accounting firms perform the same services. The resultant high audit fee is considered some form of a "bribe". Hackenbrack et al., 2014 identifies key aspects of audit quality, including audit process, auditors' attributes, audit methodology, professional judgments, auditing standards, and the tone at the top. Apart from other concerns arising from the Enron debacle and other financial scandals, the rising amounts of NAS fee compared to audit fee have led to a widespread belief of loss of integrity, objectivity, and auditor independence. Two main points of concerns are fear of loss of additional income from the auditor's client firm (self-interest and self-review threats to auditor independence), which may result in auditors avoidance of any stance against management; and a loss of professional skepticism in case of being identified closely with the management (Management threat, advocacy threat).

NAS includes activities broadly divided into the provision of consulting services such as system design related to financial information, compliance-related activities e.g. accounting and taxation services, and assurance-related services, including due diligence (IFAC \& Financial Reporting Council, Ethical Standards, 2016). Thus, categorization of allowable and restricted NAS may include activities posing threats to auditor integrity, objectivity, and independence or otherwise such as self-interest threat, self-review threat, management threat, advocacy threat, familiarity, and intimidation threats.

Prior empirical Evidence reports inconclusive results regarding the provision of NAS on auditor's independence. However, it is recognized that such provision of both services simultaneously creates bonding between both parties. It reduces cost and results in creating a spillover effect for auditors, thus minimizing the transaction costs (Hackenbrack et al., 2014). It may also result in reputational capital and thus increase auditor independence. It is worth arguing that the usage of the NAS fee as a contingent fee by the client to get the auditor biased to its opportunistic financial reporting practices can threaten auditor independence (Bettie \& Fearnley, 2001).

Prior research also demonstrates a link between audit and NAS fees with corporate performance. For example, Lee (2009) lists determinants of such association: firm size, market share, growth, inventory, debt management, advertising and R\&D expensed, and capital intensity. In addition, other determinants such as ROA, Debt to assets, Sales growth, risk measures, the board size, composition of the board, Tobin's Q, etc., are used as determinants of corporate performance used in audit studies (Yang \&Zaho, 2014).

Europe in April 2014 prohibited the provision of certain NAS to audited public interest entities (PIE's) and also established a ceiling of such NAS fees at a ceiling of $70 \%$ of the audit fee based on an average of three years (Eilifsen, Quick \& Umlauf, (2018) in response to the regulations promulgated in mid-June 2016. In Pakistan, in this regard, the amended "Corporate Governance Rules 2017 advocates;

"The external auditors shall observe applicable guidelines issued by the International Federation of Accountants concerning restriction of non-audit services. Furthermore, the audit committee shall also ensure that the external auditors do not perform management functions or make management decisions, responsibility for which remains with the Board and management of the Public Sector Company" (PSC, Amended CG Rules, 2017).

Earlier literature contends that the provision of audits and NAS to retain their clients can compromise the auditor's independence (Haniffa et al., 2011). These studies also suggest that an auditor's independence in providing both services is related to the firm's performance, thus influencing the firm value (Hay et al., 2006; Stanely, 2011).

Thus, the crux of the above discussion is based on the premise of reducing IA among owners and managers, which is one of the major functions of quality financial reporting. With the growing complexity of modern business, dependence on the quality of financial reporting is increased on accounting standards and other regulatory systems such as internal and 
external governance systems. Internal governance system is referred to BOD's, audit committees, majority shareholders and block holders, and internal audit function. In contrast, an external governance system refers to the rule of law, regulation from SECP, companies' ordinance, stock exchange, and external audit requirement. Earlier literature reports the importance of auditing and concludes that auditing provides reliable and quality financial information (Warfield, 2003).

On the other hand, some authors report that auditing affects the quality of financial reporting. Still, the Non-audit services (NAS) fee provided by such advocates also creates doubts regarding the independence of such audits. Thus, this study aims to empirically examine the effects of audit and NAS fees on the corporate performance of firms listed on the Pakistan Stock Exchange for the period 2012-2016.

This study adds to the prior literature with a growing concern regarding the joint provision of audit and NAS by the same audit firm. It creates an economic bonding with the client, thus increasing the audit firm dependence on the same firm. On the other hand, it promotes cost saving to the auditor and the creation of spillover effect (Hackenbrack et al., (2014) emphasize the creation of contingent fee as a factor compelling the auditor towards a biased view of the client financial statements. In the wake of such threats to auditor independence, this study investigates the effects of audit and non-audit services fees on corporate performance. As previously, very few studies are conducted in Pakistan, including Ahmed and Goyal (2005) and others with a little focus on audit fee effects on business while the rest of the studies focus on auditor independence. Also, most of them were studies before adopting a code of Corporate Governance in the country, including a few years' observations or focus on a few industries only. Non-audit services were also not included studies in most of the studies. Hence this study will help in filling such gaps in research on this area and will be a valuable contribution to the overall understanding of the joint provision of both audit and NAS by the same auditor to the same client and its impact on corporate performance in Pakistan.

The rest of the paper is structured as follows; the next section presents a literature review; Section 3 reports the methodological underpinning of the paper; results are discussed in section 4, while the last section concludes the paper.

\section{LITERATURE REVIEW}

The corporate information environment is influenced by the stewardship and valuation problems (Gjesdal, 1981). It can be best described as an example of a moral hazard as the latter requires the accounting system information about the firm value. In contrast, the former requires the presence of investors to observe the manager's actions. Factors linked to managerial incentives and earnings quality in the literature include weak performance, Debt having high levels, internal control deficiencies, meeting earning targets, tax regulations, and macroeconomic scenario (Kim, Chung \& Firth, 2003). While, the consequences of accounting quality include studies like Biddle, Hilary, and Verdi (2009) which propose an association of positive nature with an accounting quality of higher-level leading to a lower information asymmetry between firms and investors and consequent restraint on managers' opportunistic approach.

Asian financial crises (2007-2008) along with other renowned accounting scandals and crises like those of Enron, WorldCom, Dotcom bubble, etc. resulted in the downfall of several commercial and financial institutions of high profile resulted in regulations and policy developments for improvements in quality financial reporting through enhancements incorporate scrutiny and transparency mechanism making enactment and changes to accounting and disclosure requirements (Imhoff, 2003). However, variation in financial reporting practices leads to uncertainties and problems. With the application of IFRS, major capital market benefits like increased transparency, improvement in financial reporting practices, etc., were witnessed (EC Regulation No. 1606/2002). Consequently, many accounting bodies and the stock exchanges around the world started adopting the IFRS to attain harmonization and uniformity of the application of accounting rules (Christian Leuz, peter Wysocki, 2008).

Corporate transparency is the limit until corporation actions are observed and duly analyzed by stakeholders with a proper sense of clarity. Achieving a standard level of transparency needs compliance of the company to accurate accounting rules, disclosure of company information, showing conflict of interest of directors or the shareholders, etc. In addition, Sarbanes-Oxley Act, 2002, requires organizations to publicize the roles and responsibilities of the management and the board to clarify accountability. It also ensures that managers utilize company resources most efficiently and effectively to achieve appropriate goals without considering personal interests (Benjamin Fung, 2014).

Owing to transparency and disclosure requirements, prior literature signals the strength of the relationship between financial reporting and auditing (Hribar et al., 2014). Ullah, Shaikh, Channar, \& Shaikh (2021) report that auditing is another investor protection-oriented mechanism that provides reliable and quality financial information. Furthermore, research indicates that the variation in audit fees is a signal of fluctuation in the company's performance in the years to come (Stanley, 2011), thus resulting in financing through a higher cost of capital. Auditor credibility is of core importance for the auditing profession itself too. Such independence in action and appearance is important for adding credibility to the overall image of the auditee and the overall image of the auditor. This appearance and appearance have an acknowledgment from several professional accountancy bodies (ICAEW, 2006; AICPA, 1988). A competitive market of the external auditor also developed resultantly, which provided authenticated financial statements and provided consultancy and advisory services with varying degrees of charges ( 
Several studies have used governance mechanisms to explain the mechanism of audit cost; however, results have not reached any defining conclusions. The effect of ownership structure on audit cost is also found to have conflicting results. Companies with majority shareholdings tend to have lower audit costs than firms with foreign subsidiaries (Niemi, 2005). Adelopo, Jallow, and Scott (2009) concluded that firms with large shareholders monitor firms and thus have lower audit costs than firms with more dispersed ownership. Higher audit fees reflect costly signaling to the market regarding a higher degree of investment in financial statement verifications or disclosure (Jordan, 2010). U1lah, Shaikh, Channar, \& Shaikh (2021) in contradictions, to the association of higher amounts of audit fee with the deliberate investment in financial statement verification, argues that such an attempt may be linked to the attempt to bribe the auditor in the form of economic rent creating and economic bond with the clients as compared to the payment of normal audit fees.

Stanley, (2011) considers the provision of audit and non-audit services in tandem (joint provision) as a means of producing knowledge spillover, resulting in the reduction of audit risk and thus increasing audit quality. However, unanimous results in this regard have not been established as advocates like Stanley (2011) found a positive relationship, while studies including those of Whisenant, Sankaraguruswamy \& Raghunandan (2003) found no relationship in this regard. Some studies, on the other hand, found a beneficial relationship between both kinds of fees. In contradiction to the differences, however, doubts regarding compromising auditor independence in maintaining client and income persist in literature (Haniffa et al., 2011; Hay et al., 2006).

\section{Audit and Non-Audit Services}

Niemi, (2005) presents the pioneer empirical Evidence on the pricing of the audit services. His pioneer efforts paved the way for further insight in different countries, but his model's pattern remained the same with little alterations. According to Stanley (2011), audit price is a function of; (i). Resources utilized by the auditor. (ii). The opportunity cost of conducting the audit. He further elaborates that fees charged for audit are comprised of client-specific and auditorspecific. Stanley, (2011) also contends that such joint provision of services may result in a knowledge spillover, thus reducing the audit engagement risk, thus increasing the audit quality (Beck \& Wu, 2006: Francis, Jere R. 2004). Conflicting results are witnessed in this regard Stanley (2011) findings contribute to the positive relations while studies like those of Whisenant, Sankaraguruswamy \& Raghunandan (2003) suggested results to the contrary. Audit fees and non-audit fees jointly create a general perception of effecting the auditor's independence in the context of the client and the income (Haniffa et al., 2011; Hay et al., 2006).

The auditor's independence from the point of view of the provision of non-audit services by the same auditor considering the agency problem is avoided by most companies (Svanström, Tobias 2012). Studies, including those of Tepalagul \& Lin (2014), prove the effects of different parties, including shareholders, directors, and audit committees. Still, mostly the effects are observed from the shareholder's approval point of view of providing such NAS. Stanley, (2011) results show no such relationship, but Raghunandan (2003) reports such a positive relationship, while Mishra, Raghunandan, and Rama (2005), suggest that NAS depends upon the kind of such voting. (Abbot, Parker, Peter \& Raghunandan, 2003) found that the existence of an effective board relies on less NAS from the same auditors.

Stanley, (2011) models the economic bond between the auditor and the auditee to increase the auditor's dependence on the client firm. No audit fee charged increases the client auditor bond further by increasing the part of audit firm wealth earned from the client. NAS also poses a threat in the client's scenario, using it as a contingent fee. Magee and Tseng (1990) note that auditing standards prohibit even contingent fees; clients still can use them by withholding profitable NAS if the auditor does not allow the client to report its preferred financial condition. Ashbaughet. Al. (2003) findings suggest that the total fee, i.e., audit and non-audit services fee, best depicts the embedded economic bond between the auditor and the client, unlike the fee ratio, which depicts the two fees' monetary value the auditor independence.

Meeting earning benchmarks or the level of discretionary accruals suggest auditor independence from three perspectives, i.e., an independent auditor requires an unbiased financial report, earning management (EM) represent a degree of biasness inserted by the management and approved/supported by the auditor, meeting earning the management again supports forecast is not random (Larcker, D., F., \& Richardson, S., A., 2003). Prior research demonstrates links between audit and NAS fee and corporate performance as Lee (2009) defines the determinants of such a link in terms of the general economic conditions, e.g., firm size, growth, market share, inventory and debt management, advertising, R\&D expenses, and capital intensity. Other determinants such as ROA, Debt to assets, Sales growth, risk measures, the board size, composition of the board, Tobin's Q, etc. are also used as measures of such measure of corporate performance in the context of overall audit fee measure (Yang \& Zaho, 2014).

\section{Audit Committee}

SOX act (2002) mandates the creation of audit committees. Being part of the board of directors, its members are independent of management. They are apprised of responsibilities like selection, compensation, and oversight of the external auditors. Thus, the audit committee having nonparticipation of the management is the initial source of contact for the external auditor. It includes a financial expert with expertise in accounting standards, internal controls, understanding of financial statements preparation, auditing, and evaluation. Strong financial statements should disclose 
all of the material off-balance sheet transactions and activities that affect the overall firms' current and future financial conditions. Such material changes must be reported frequently.

Daniel and Neal (2006) conclude that audit committee members provide Evidence that auditor for the execution of NAS undermines the over auditor independence. Results of surveys show unlike allowance of members of the audit committee of audit and NAS together. US Securities and Exchange Commission in 2002 rules out the audit committee approval regarding the provision of NAS even if they improve audit quality as they perceive it as damaging to overall investors' confidence.

\section{Market-based Studies}

Market-based studies usually use archival data and variables consisting of accruals (discretionary), cumulative abnormal returns, and earning response coefficient kind of market-based multi regression (Khurana \& Raman, 2004). Joint provision of audit and NAS has conflicting Evidence in literature like Frankel et al., (2002); Khurana \& Raman, (2004) findings suggest that provision of audit and NAS together does not affect auditor's independence. However, a researcher like Stanley, (2011), advocates the absence of any compromise of auditor independence.

\section{Behavioral or Experimental Studies}

Recent contributions to behavioral or experimental studies in pursuance to the contributions by Stanley, (2011) another proposition to the solution of the issue of joint provision of audit and NAS and auditor independence, a bank loans officer possible perception in terms of personnel management can be bifurcated into five different situations; (1) provision of external audit and outsourcing of internal audit to the same auditor using different personnel team (2) provision of both services by distinct CPA firms (Ullah, Afghan, Afridi, 2019).

Abbot et al. (2007), considers the uses of the differential effect of utilizing routing NAS and non-routine NAS on independence. His findings are consistent with those of Beck \& Wu (2006) that such independence depends upon the type of NAS being engaged in. As it is established that non-routine NAS does not create any economic bonding, it does not impair the auditor's independence compared to the routine NAS. Keeping in view the important contributions by extant prior literature on the perspective, it is summed up that crucial questions raised so far remain unaddressed.

\section{Regulatory Background}

Following the emergence of several accounting and financial scandals of early 2000 have given rise to regulations such as the Sarbanes-Oxley Act of 2002 and prohibiting CPA firms from such provision of audit and NAS together to their respective clients. Such prohibitions include the following functions but are not limited to;

1- Financial reporting system designing and implementations.

2- Valuation and appraisal activates of similar nature.

3- Accounting records maintenance and other bookkeeping services.

4- Management Advisory Services.

5- Related actuarial services.

6- Outsourcing of the internal audit as well as human resource services.

7- Services related to direct legal and aligned services.

8- Involvement in investment advisory, banking, and broker services.

\section{Empirical Studies on Non-Audit Service}

NAS provision in some jurisdictions has been observed to show no disclosure requirements, so the survey method is adhered to. However, in the UK, the ratio of NAS to AF has raised to 300\% for FTSE 100 companies from 98\% in 1996, with chunks of NAS around the provision of Taxation services (compared to the US). Researchers also investigated the NAS purchase decision from its three aspects, i.e., the choice of auditor, the kind of services required, and the amount of NAS required in brief. It is also argued that companies with higher agency costs need the audit as a monitoring device. However, the value of the audit is reduced if there are independence concerns, so companies with high agency costs are predicted to purchase less NAS from their auditor.

The majority of studies also indicate that such NAS provision lowers the expected auditor's independence. These studies suffer from the risks of non-response bias and demand effects. In related strands of literature, it is found that (i) actual auditor independence in settings where joint provision occurs tends to increase as they become more critical when faced with the self-review threat and increase their effort generally; and (ii) the introduction of disclosures regarding.

NAS provision by auditors fails to result in significant changes to NAS purchase decisions (the decision feedback loop) or negative share price reactions (which represent investors' perceptions in the aggregate). 
Strand of literature covering cases of alleged audit failure seems to fall behind in showing the importance of such joint provision of NAS as a significant feature of the literature in this regard. Only recently, studies have begun to examine whether the provision of NAS impacts upon the attributes of accounting numbers. The rationale for these studies is that earnings quality (measured in terms of the degree of earnings management) is, in part, a function of auditor independence. The level of earnings management is commonly measured in terms of discretionary accruals, and this requires the level of normal accruals to be modeled. Once again, the Evidence is mixed. Some studies find that NAS provision is negatively associated with earnings quality while others do not. One or two studies find this association only for small auditors. The difficulties with this line of research lie in measuring the proxy variable for auditor independence and the validity of the proxy itself.

\section{RESEARCH METHODOLOGY}

This section reports an overview of the methods used in this study. It reports the research design, population, sample, data collection, and models used.

\section{Population and Sampling}

The total population comprises financial and non-financial companies listed on the Pakistan Stock Exchange (PSX-100 Index) for 2012-2016. The non-financial sector is taken as a sample of the study. A company is included in the sample based on data availability for the entire period of 2012-2016. As per this criterion of convenient sampling, a total of 257 companies' data is available and is taken as a sample of the study totaling 1285 firm years observations. The data includes companies from textile, chemical, construction, and cement, food producers and processors, general products producers, oil sector, automobiles manufacturers, assemblers and accessories producers, cables and electrical equipment manufacturers, fertilizers, leather, and tanneries, sugar mill sector, etc.

Companies listed on PSX strictly adhere to the application of prevailing reporting standards, company laws, and other Securities and Exchange Commission of Pakistan (SECP) regulations; thus, the chance of visibility of using NAS more than the prescribed limits are prominent. Knowledge, expertise, capabilities, experience count in such calculation of audit and non-audit services. The analysis comprises univariate and multivariate analysis.

\section{Regression Model}

To investigate the association of AF and NAS with FP, the following model is proposed;

$$
\begin{aligned}
& F P=\alpha+\beta A F+c N A S+d C V+e \\
& F P=\alpha+A F_{i t}+c N A S_{i t}+d C V_{i t}+e_{i t}
\end{aligned}
$$

Where FP is firm performance and is proxied by earnings per share (EPS), return on equity (ROE) and Tobin's Q; AF is audit fee and is proxied by the total audit fee charged by the auditor from the firm; NAS is non-audit services fee charged by the same firms using different measurements of NAS fees. NAS is measured as the total contingent fee reported in financial statements. In inconsistency with the literature, a natural logarithm of NAS fee reduces its variability (Ashbaugh, LaFond\& Mayhew, 2003; Ullah, Malik. Zeb, and Rehman, 2019).

\section{Variables}

Data for most of the variables included in equation (1) is taken from the financial statements of 257 listed non-financial firms on the PSX-100 index. Empirical Evidence suggests that audit firms determine their audit fees based on the client's characteristics, including that of firms' financial condition. In assessing the relationship between the audit fee and firm performance measures, a set of variables are determined, including EPS, ROE, ROA, TQ. Earnings per share (EPS), which is an indication of financial as well as the operating health of an organization in terms of performance of the managers (stewardship) as it denotes the availability of the earnings to each of the shareholders (Bhagat \& Bolton, 2008). Return on equity represents the number of earnings available to the equity shareholders after payments of all outstanding payments in terms of interest, dividends, etc. hence, it is the key ratio determining the firm's performance (Sami, Wang \& Zhou, 2011). Return of assets is the ratio showing the efficiency of the management in running the business. Thus it is frequently used in literature to judge the firm performance (Lee, 2009). While, Tobin's Q is a measure of assessment of firm performance from the point of view of determining its value from the point of view of the market position/value (Gompers et al., 2003).

An audit fee is the combination of all the fee's allowed by statutes to be the true representative of the efforts of the auditor's in giving the audit opinion. It varies due to the size of the auditee and the auditor, so it is taken in logs. Nonaudit fees are represented by the amount of fee paid for the consultancy services regarding taxation, corporate law, etc., and are again taken in logs.

\section{Results}

This section covers the results of this study. Methods include the use of univariate analysis and multivariate analysis. The univariate analysis includes the descriptive statistics covering the mean, median, and standard deviation analysis. While the multivariate analysis includes the use of Pearson correlation analysis and regression analysis includes 
regression of analysis as given in the regression model. Descriptive statistics of variables included in the equation are presented in Table 4.1, while Table 4.2 represents the correlation results of the study variables.

\section{Univariate Analysis}

The univariate analysis covers descriptive statistics such as mean, median, standard deviation, minimum, maximum, skewness, and kurtosis values. Mean is a measure of the central tendency of the data, giving the centrality of the spread of the variables. Median is an indication of the centrality of the mean values of the data. Standard deviation gives the dispersion of the variables. Skewness indicates the direction of the spread of the mean value. In contrast, the kurtosis indicates weakness or pointiness of the data showing the presence or absence of the outliers.

Table 1: Descriptive Statistics: EPS, ROE, ROA, TQ, AF, TA, SALES, DT

\begin{tabular}{llllllll}
\hline Variable & Mean & StDev & Min & Med & Max & Skew & Kurt \\
\hline EPS & 0.85 & 0.73 & -2.63 & 0.90 & 2.93 & -0.57 & 0.97 \\
\hline RoE & 1.11 & 0.50 & -1.74 & 1.19 & 3.10 & -1.14 & 3.79 \\
\hline RoA & 0.74 & 0.52 & -2.14 & 0.84 & 1.83 & -1.26 & 2.97 \\
\hline TQ & 0.04 & 0.31 & -2.43 & -0.02 & 3.12 & -1.12 & 2.77 \\
\hline AF & -0.06 & 0.37 & -1.40 & -0.09 & 1.12 & 0.18 & 0.67 \\
\hline NAS & -0.31 & 0.62 & -2.10 & -0.36 & 2.18 & 0.23 & 0.23 \\
\hline Sales & 3.66 & 0.85 & 0.20 & 3.69 & 6.08 & -0.68 & 1.72 \\
\hline DT & 2.74 & 0.99 & -1.25 & 2.77 & 5.02 & -0.53 & 0.53 \\
\hline
\end{tabular}

Results of descriptive analysis of dependent; EPS (Earning per Share), ROE (Return on Equity), ROA (Return on Assets), TQ (Tobin's Q) while, Independent variables; AF denoting (Audit Fee), NAS (Non-audit Services) Fee, TA denotes (Total Assets), Sales and DT denotes Debt of companies.

The four-firm performance measures consisting of EPS, ROE, ROA, TQ are having values that can be best described as; EPS is having a minimum value of -2.63 and maximum value of 2.93 and a mean of 0.85 , meaning by that spread of EPS has a central tendency and its mean fall within the range of spread. It is also commended by the fact that its skewness value is -0.57 , and as standards suggest, this value should fall between 1 and -1 , and the Kurtosis value of 0.97 is within the range of common value 3 . It is important to note here that skewness depicts the asymmetry of the spread about the mean value. At the same time, kurtosis shows the data's weakness or the presence of outliers in the data showing data falling beyond the spread surrounding the mean value. Finally, ROE has a minimum value of -1.74 , and maximum value of 03.10, and a mean of 1.11, which again reiterates that since means are within the range of minimum and maximum values. Hence, there is a trend towards central tendency, but skewness and the kurtosis schemes show raised values, thus pointing to certain outliers in the said data.

The third firm performance measure of ROA depicts a minimum value of -2.14 , and maximum value of 1.83 , and a mean of 0.74 , showing the tendency of data to fall within the range of its minimum and maximum value the trend of more skewness towards the negative side. TQ having a minimum value of -2.43 , and maximum value of 3.12 , and a mean of 0.04 , with data more skewed towards the positive side and a high kurtosis, depict extreme outliers that need to be brought into perspective. It is also based on the fact that market values tend to variate due to the firm's variability of performance, size, complexity, etc. Control variables, such as leverage, have statistics of a minimum value of -1.25 , and maximum value of 5.01, and a mean of 2.74. This shows the data spread is negatively skewed, but extreme outliers are not found, as depicted by the kurtosis value of 0.53 .

Size variable as proxied by the assets, which has a minimum value of 0.97 and maximum value of 6.27 with a mean of 3.75. Similarly, sales growth has a minimum value of 0.20 , a maximum value of 6.08 a mean value of 3.66 . Both of these values show that the symmetry of the data is negative, but the chances of the presence of outliers are less as Kurtosis values for both variables are within the standard. Independent variables of audit fee and NAS fee have their mean value central to the data, and the symmetry is positive. Data is also normally inclined to the center, as presented by its descriptive results. NAS has a mean value of -0.31 minimum value of -2.10 and a maximum value of 2.18 .

Since the mean and median statistics show that the spread of each of the dependent and independent variables are almost evenly populated as all the mean values fall in the range between minimum and maximum values, most of the variables, however, show negative skewness, meaning by that its distribution is to the right side of a mean value or in other words some of the outliers are present in data, which is dealt with in the later stages of this study. Non-audit service's maximum ceiling is, however, found to be higher than the maximum audit fee paid to the auditors. Debt ratio as compared to the assets is also found at a higher rate. Overall performance of the corporate sector seems to be average as the ratio's deviated from negative margins to 2-3 times in EPS and ROE. While TQ falls at a value of 3, this is higher because state-owned enterprises usually have higher debt ratios and negative earnings. 


\section{MULTIVARIATE ANALYSIS}

The multivariate analysis includes the correlation and Regression analysis. Table 2 reports the correlation analysis followed by regression analyses of dependent and independent variables of this study.

\section{Correlation Analysis}

Correlation measures the relationship among variables. It represents the linear relationship and is denoted by the correlation coefficient. The standard range of this coefficient is between -1 and 1 , while 0 falls in between showing no relationship. Ullah, Malik. Zeb, and Rehman, (2019) report that the problem of multicollinearity occurs if the correlation between the variables exceeds 0.9 .

Table 2: Correlation Analyses of EPS, ROE, ROA, TQ, AF, NAS, TF, TA, Sales, DT

\begin{tabular}{|c|c|c|c|c|c|c|c|c|}
\hline & EPS & RoA & RoE & TQ & $\mathbf{A F}$ & NAS & TA & Sales \\
\hline Ron & $0.46 * * *$ & & & & & & & \\
\hline RoE & $0.22 * * *$ & $0.30 * * *$ & & & & & & \\
\hline TQ & $0.19 * *$ & $0.29 * *$ & $0.15^{* * *} *$ & & & & & \\
\hline $\mathrm{AF}$ & $0.16 * * *$ & $0.09 * *$ & 0.05 & $0.12 * * *$ & & & & \\
\hline NAS & $0.06 *$ & 0.03 & 0.02 & $0.11 *$ & $0.28 * *$ & & & \\
\hline TA & $0.06 *$ & $0.11 *$ & $0.05^{*}$ & 0.04 & $0.57 * * *$ & $0.20 * * *$ & & \\
\hline Sales & $0.29 * * *$ & $0.24 * *$ & $0.13 * *$ & $0.08 * *$ & $0.52 * *$ & $0.40 * *$ & $0.40 * *$ & \\
\hline DT & $0.10^{* *}$ & -0.024 & 0.02 & 0.06 & $0.40 * *$ & $0.20 * *$ & $0.40 * *$ & $0.60 * *$ \\
\hline
\end{tabular}

***,**,* represent $1 \%, 5 \%$ and $10 \%$ level of significance.

EPS is earnings per share; ROE is a return on equity; ROA is a return on assets; TQ is Tobin's Q; while AF is Audit Fee; NAS is non-audit service fee; while TA is total assets; Sales are sales of the firm and DT is total Debt of a firm.

Pearson correlation matrix results as given in Table 2 are detailed below. The analysis indicates a significant relationship of Audit fees with EPS, ROA, and TQ. P-value, in this case, is less than the alpha level of 0.05. Correlational relationships with these strong performance indicators exist at about $0.158,0.093$, and 0.118 , respectively. This can be categorized into a positive correlation of near to moderate with EPS, ROA and TQ, but a suggestive relationship exists with ROE. Similarly, a significant $(\mathrm{P}<0.005)$ correlation is noted with coefficients of near to moderate between NAS and TQ. Indicating the fact that with an increase in AF and NAS fees, the firm's performance tends to improve.

A largely positive correlation is observed between the control variable such as TA and AF, NAS at the levels of 0.567 and 0.185 . The level of significance being denoted by $\mathrm{P}$ is lesser than 0.005 , indicating the significance of the relationship. It is consistent with the literature that as the assets of the firms increase, the audit fee tends to increase due to extra efforts, increased number of professionals, increased risk of the wrong audit opinion, etc. However, correlation is at a lower level than firm performance measures like those of EPS, ROA, ROE, and TQ at a level of 0.056, 0.070, 0.048 , and 0.041 , respectively. This is because larger companies obtain benefits from economies of scale and a larger market share, thus positively affecting corporate performance (Lee, 2009). Literature also includes views related to the negative relationship of assets with firm performance measures (Anderson \& Reeb, 2003). Therefore, there is no such consistent evidence in the literature regarding such a relationship.

Sales growth increases revenue, thus positively correlating with the performance measures (Lee, 2009). A similar pattern is observed among sales and firm performance measures of EPS, ROA, ROE, and TQ at a rate of 0.290, 0.241, 0.125, and 0.081 . The level of significance was consistently below the threshold of 0.005 . Leverage is represented by the ratio of long-term Debt to total assets. Literature suggests a negative sign of its correlation coefficient with ROA in case of higher leverage levels (Lee, (2009); Yang \& Zhao, 2014). Values for correlational coefficients relating to EPS, ROA, ROE, and TQ are found to fall at $0.097,-0.024,0.014,0.056$, and 0.395 , respectively. In such a relationship with ROE, the sign of the coefficient depends upon earning power and cost of Debt (Yang \& Zhao, 2014).

\section{Regression Analysis}

The regression equation is developed based on the assumption that Audit and NAS jointly affect the firms' performance in Pakistan. The literature describes the provision of NAS provision affects the auditors' independence and the audit quality. Thus the quality of financial reporting is affected resultantly (Daoud et al., 2015).

\section{Panel Regression Model}

A certain yardstick for the rejection of the Null hypothesis of parameter stability is set, which does not reject it if the $\mathrm{F}$ value does not exceed the limit set by the $\mathrm{F}$ table at a specific significance level justifying the adoption of pooled regression. While, on the other hand, if the $\mathrm{F}$ values exceed the critical $\mathrm{F}$ values, then pooled regression needs not be adopted. As per the designated standard, values falling below the threshold of 2 favor adopting the fixed effects model. Thus, the Hausman test is run to select among the Fixed Effect and Random-effects models for each of the independent 
variables proxying the firm Performance and the firm value measures. A consolidated table in this regard showing the relevant values for a selection of Fixed Effects (FE) or Random Effects (RE) model is given as under:

Table 3: Hausman test statistics

\begin{tabular}{lllll}
\hline Dependent Variable & Chi-Sq. Statistics & Chi-sq. D.F & Probability & Test Summary \\
\hline EPS & 30.186 & 8 & 0.000 & FEM \\
\hline ROE & 57.573 & 8 & 0.000 & FEM \\
\hline ROA & 38.001 & 8 & 0.000 & FEM \\
\hline TQ & 18.434 & 8 & 0.018 & FEM \\
\hline
\end{tabular}

FEM, REM represent Fixed Effect Model and Random Effect Model, respectively.

As given in Table 3, the Hausman test has resulted in an overall significance level below the 5\% threshold level; hence, a fixed-effects model is selected. As per the set standards, more than $50 \%$ of variables have a p-value at a significance level, thus recommending the model's fitness under consideration. R2 denotes the joint explanation of the regresses regarding the outcome expressed by the dependent variable (predictors). Here, the R2 value is $89.78 \%$, meaning that the model is explained by $89.78 \%$ by the relevant variables, and the remaining (100-89.78) is explained by some random variables. Also, it denotes the goodness of the model fit at the sample level. The probability of F-statistics was also found significant at 0.0000 , explaining the joint significance of the regresses at the population level, thus giving the model fitness at the population level. Durbin Watson statistics (1970) states that if its test value exceeds 2, there is no autocorrelation issue among the residuals of the study. Hence Durbin Watson's value is measured at 2.049.

\section{Results Panel Data Analyses}

Since panel data combines some features of time series and cross-sectional data, the panel data regression model is used to evaluate the effects of both features. This method is useful in establishing heterogeneity, having a lesser chance of collinearity, and more freedom. Pooled regression is applied to the data using combining all observations for all the firms, and a common regression is run. Although the panel regression model is based on time series, certain structural changes between the regress and the predictors' relationship may occur as the parameters of the data do not remain constant over the entire period under consideration. These changes may be caused by the difference in slope coefficient or the regression intercept or both simultaneously. The best practice, in this case, is the use of the Chow test, which assumes the independent and normal distribution of the error terms and the parameters stability scenario (no structural changes). Therefore, in this case, the chow test or F-test is applied, which results in a value falling under 2.

Results of regression analysis indicate that EPS upon regression with the independent variables, i.e., AF and NAS, has a negative coefficient. The significance value of the P-value for such a regression is found at a level well below the threshold of 5\%, creating a $95 \%$ confidence in the result. It indicates an inverse relationship that describes that an increase in NAS causes a subsequent decrease in EPS and thus the performance measures of firms. The same pattern corresponds to the results, as evidenced in the literature (Stanley, 2011). Results for ROE indicates a significance level having a negative association with AF and NAS meaning an increase in AF and NAS causes a subsequent decrease in firm performance measure like ROE. These results are consistent with prior literature (Santos, 2016). ROA also has a negative association with AF, NAS, TA, and sales, respectively. Trends prevailing in the earlier literature regarding the negative relationship of ROA with AF are also evidenced in our analysis. Similar results are also reported for Tobin's Q. Tobin's Q represents comparing the overall market capitalization of firms to its book values, resulting in either overvaluation or undervaluation of firms. Use of this ratio is evidenced from literature (Alali, (2011); Stanley, (2011). Regressing TQ with AF \& NAS shows a negative relationship proving its negative relationship with the firm value measures, which is an extension of firm performance.

Table 4: Panel Data Analyses of EPS, ROE, ROA \& TQ VS AF, NAS, TA, SALES \& DT

\begin{tabular}{|c|c|c|c|c|c|c|c|c|c|c|c|c|}
\hline \multirow{2}{*}{ Variable } & \multicolumn{3}{|c|}{ Panel A: EPS } & \multicolumn{3}{|c|}{ Panel B: RoE } & \multicolumn{2}{|c|}{ Panel C: } & \multirow{2}{*}{$\begin{array}{l}\text { RoA } \\
\text { p-value }\end{array}$} & \multicolumn{3}{|c|}{ Panel D: TsQ } \\
\hline & Coef. & t-value & p-value & Coef. & t-value & p-value & Coef. & t-value & & Coef. & t-value & p-value \\
\hline $\mathrm{AF}$ & -0.350 & 2.290 & 0.022 & -0.001 & 3.152 & 0.001 & -1.090 & -2.769 & 0.005 & -0.001 & 3.022 & 0.002 \\
\hline NAS & -0.012 & 1.258 & 0.020 & -0.310 & 0.848 & 0.396 & -0.323 & 0.735 & 0.462 & -0.010 & 1.745 & 0.082 \\
\hline TA & -0.010 & 0.093 & 0.925 & 0.010 & 1.786 & 0.074 & -1.751 & -3.996 & 0.000 & -1.013 & -3.649 & 0.000 \\
\hline SALES & 0.145 & 1.954 & 0.051 & -0.184 & -2.085 & 0.037 & 0.124 & 1.110 & 0.267 & 0.003 & 2.135 & 0.033 \\
\hline DT & -0.052 & 1.420 & 0.156 & -0.058 & -0.410 & 0.681 & -0.232 & -1.649 & 0.099 & 0.059 & 0.676 & 0.499 \\
\hline
\end{tabular}

The table reports Panel Data Analyses of EPS, RoE, ROA, and TsQ with AF, NAS, and control variables. EPS is earnings per share; RoE is a return on equity; RoA is a return on assets; TsQ is Tobin's Q while AF is Audit Fee; NAS is non-audit service fee; while TA is total assets; Sales are sales of the firm and DT is total Debt of a firm.

Control variables like TA and DT regression show a significant negative effect on firm performance measures like ROE, ROA, and TQ in the case of TA. In contrast, in the case of the DT control variable, the firm performance measures like EPS and ROA have a negative relationship with firm performance measures. This finding is consistent with Martinez et al. (2014). In addition, NAS affects firm performance by limiting the auditor independence leading to lower financial 
performance. On the other hand, sales (control variable) present a significantly positive relationship with a firm performance measure and firm value measures, which is consistent with the findings of Lee (2009).

\section{DISCUSSION AND CONCLUSION}

Evidence from literature has shown that auditor independence is key to quality financial reporting. However, others report also include the NAS fee charged by the same auditors as a factor creating doubts regarding the auditor's independence (Fang \& Wong, 2001). Thus, this study focuses on this aspect of auditor independence by evaluating the joint provision of AF and NAS fee effect on firm performance in Pakistan.

An updated data for 2012-2016 has been taken from companies' financial statements listed on the PSX-100 index. Nonfinancial companies' financial performance parameters are taken as dependent variables, including EPS, ROE, and ROA as a direct measure of firm performance. Furthermore, TQ is taken to evaluate the relevant firm value from the market's point of view. In addition, AF and NAS are taken as independent variables, while total assets, sales growth, and leverage are taken as control variables. The sample comprises an average total of 257 companies for the year 2012-2016, making 1542 firm-year observations of the panel data.

Descriptive statistics are used to determine the centrality of the spread and the presence of extreme outliers in the data. NAS is found to be at a raised level as compared to the AF. Keeping in mind the linearity of the data, the relationship between the firm performance and the firm value-dependent variables is assessed with the help of correlation analysis by using the Pearson correlation matrix technique. The resulting analysis indicates a significant relationship of Audit fees with EPS and ROA measures. In most cases, P-value is found to be at a level less than the alpha of 0.05 . The correlation relationship with these strong performance indicators can be categorized into a positive correlation of near to moderate with EPS and ROA. A significance of $\mathrm{P}<0.005$ is recorded in coefficients of NAS with EPS.

A significant correlation of lower level is observed between assets (firm size) with AF, NAS at a level of significance lesser than 0.005 . However, the literature includes views related to the existence of the negative relationship of assets with firm performance measures (Anderson \& Reeb, 2003) and also significant positive relationship (Lee, 2009). Therefore, there is no such consistent evidence in the literature regarding such a relationship. Sales growth increases revenue, thus positively correlating with the performance measures (Lee, 2009). A similar pattern is observed among sales and firm performance measures of EPS and ROA; the significance level was consistently below the threshold of 0.005. Literature suggests a negative sign of correlation coefficient of leverage with ROA, in the case of a higher level of leverage (Lee, (2009); Yang \& Zhao, 2014). Other studies in this regard, like that of (Santos, Cerqueira, and Brandao, 2015), also found a negative relationship of NAS with firm performance measures indicating an increase of NAS causes a decrease in firm performance measures.

Using regression analysis, the nature of the relationship among variables is established. Results here depict an established and significant negative relationship between the audit fee independent variable and the firm performancedependent variables. Panel data analysis technique is used to determine the fixed effect (FE) and random effect (RM) models. Hausman test recommends the use of RE in the case of EPS with other variables. The majority of the variables showed P-value below 5\%, thus indicating the fitness of the model. While Durbin Watson test was also near the threshold of 2.0, indicating almost the absence of autocorrelation. F value of the test was also significant at a level of 0.0000. The negative sign of the NAS again showed the existence of a negative relationship with the FPM's.

While the ROA model with the rest of the variables shown in its Hausman test, a P value of less than 5\%, indicating the rejection of the Null Hypothesis and adoption of "Alternate," which precludes the adoption of the FE model. More than $50 \%$ of the variables have P values less than the significance level, hence recommending the fitness of the model. The $\mathrm{R} 2$ results express the joint explanation of the independent variables regarding the dependent variable's outcomes. It also denotes the goodness of the fit of the model. R-Squared results into $89.86 \%$, meaning that the model is explained by $89.86 \%$ by the relevant variables in consideration. Some random variables explain the rest (100-89.86) as the fixed effects model uses dummy variables, so the existence of higher R-Squared is almost evident. The probability of Fstatistics was also found significant at 0.0000 , explaining the joint significance of the regressors at the population level, thus giving the model fitness at the population level. Durbin Watson's statistics (1970) also have a value indicating the absence of an autocorrelation issue among the residuals of the study.

Thus, the statistical outcome concludes that AF and NAS are negatively significant with FPM's like EPS and ROA. This negative relationship of NAS with the firm performance measure indicates a negative corporate performance trend related to an increase in AF and NAS, consistent with the literature (Martinez et al., 2014). Firm size is found to have a positive relationship with total audit fee, sales volatility, or growth. It has a positive relationship with performance except with EPS and ROA, in tandem with Lee (2009). Long-term Debt has a negative impact on ROA (Lee, 2009; Sami et al. 2011; Ullah, Afghan, Afridi, 2019; Yang and Zhao (2014).

\section{LIMITATIONS AND FUTURE RESEARCH}

The current study is limited to the provision of audit and non-audit services jointly by the same audit firm on the corporate performance of firms in the capital market of Pakistan, however the future investigation into such a relationship between AF \& NAS with other FPM's at the Pakistan level would be an interesting addition. Various 
avenues in this regard are waiting to be explored. Among the list are the use of recurring and non-recurring nature of NAS, establishing such relationship using the size of the auditee and the auditor, the inclusion of audit firms according to its reputation, use of accruals of all natures, lag reporting, type of ownership (family nature of business existence in the Pakistani context), multi-period audit engagement, auditor independence concerns from the point of view of its reputation, regulatory and legal/litigation aspect and also study of the association between client and audit independence using the issuance of various kinds of reports like modified/qualified and going concern opinion and also using other corporate governance indexes and measures.

\section{RECOMMENDATIONS}

The present study is recommended to regulators as well as standard setters in Pakistan that implies the bifurcation of audit services provision and its serious implications on the corporate sector.

\section{AUTHORS' CONTRIBUTIONS}

Muhammad Naeem Khan: Writing abstract and references, Data Collection.

Adnan Ahmad: Data Analysis and its interpretation, review of the article after completion, and correspondence with the journal.

Muhammad Asad Khan: Data Collection, writing contribution for future research.

Aziz Javed: Working on literature, discussion, and conclusion.

Zia ur -Rehman: Refine the manuscript with APA formatting of the text, citations, and references.

\section{REFERENCES}

1. Ahmed \& Goyal (2005). A comparative study of pricing of audit services in emerging economies. International Journal of Auditing, 9 (2), 103-116. https://doi.org/10.1111/j.1099-1123.2005.00236.x

2. Adelopo, Jallow and Scott (2009). Multiple large ownership structure, audit committee activity and audit fee: Evidence from the UK. Journal of Applied Accounting Research, 13 (2), 100-121. https://doi.org/10.1108/09 675421211254821

3. Ashbaugh et al., (2003). Do Non-audit services compromise auditor independence? Further Evidence. The Accounting Review, 78(3), 611-639. https://doi.org/10.2308/accr.2003.78.3.611

4. Abbot et al., (2007). Corporate Governance, audit quality and the Sarbanes Oxley Act: Evidence from internal audit outsourcing. The Accounting Review, 82(4), 803-835. https://doi.org/10.2308/accr.2007.82.4.803

5. Anderson, R. \& Reeb, D. (2003). Founding family ownership and firm performance: Evidence from the S\&P500. Journal of Finance, 58, 1301-1328. https://doi.org/10.1111/1540-6261.00567

6. Alali, F. (2011). Audit fee and discretionary accruals: compensation structure effect. Managerial Auditing Journal, 26(2), 90-113. https://doi.org/10.1108/02686901111094994

7. Biddle, G. C, Hilary, G., \& Verdi, R. S, (2009). How does financial quality relate to investment efficiency? Journal of Accounting and Economics, 4(3), 341-352. https://doi.org/10.2139/ssrn.1146536

8. Beck \& Wu, (2006). Learning by doing and audit quality. Contemporary Accounting Research, 23(1), 1-30. https://doi.org/10.1506/AXU4-Q7Q9-3YAB-4QE0

9. Bhagat S., Bolton B., Romano R. (2008). The promise and peril of corporate governance indices. Columbia law review, 108(8), 1803. https://doi.org/10.2139/ssrn.1019921

10. Daoud, K., D. Al-Sraheen \& N. Alslehat (2015). The moderating effect of an audit committee on the relationship between non-audit services and corporate performance. Research Journal of Finance and Accounting, 6(14), 170-179.

11. Eilifsen, Quick \& Umlauf, (2018). Investor's perception of non-audit services and their types in Germany: The financial crises as a turning point. International Journal of Auditing, 22 (2), 298-316. https://doi.org/10.11 11/ijau.12121

12. Francis, Jere R. (2004). What do we know about audit quality? The British Accounting Review, 36(4), 345-368. https://doi.org/10.1016/j.bar.2004.09.003

13. Frankel R., Li Xu. (2004). Characteristics of a firm's information environment and the information asymmetry between the insiders and outsiders. Journal of Accounting Economics, 37 (2), 229-259. https://doi.org/10.1016 j.jacceco.2003.09.004

14. Fung B. (2014). The demand and need for transparency and disclosure in corporate Governance. Universal Journal of Management, 2 (2), 72-80. https://doi.org/10.13189/ujm.2014.020203

15. Gompers, P., J. Ishii \& A. Metrick (2003). Corporate Governance and equity prices. The quarterly Journal of Economics, 118(1), 107-155. https://doi.org/10.1162/00335530360535162

16. Hay, D., W. R. Knechel and V. Li. (2006). Non-audit Services and Auditor Independence: New Zealand Evidence. Journal of Business Finance \& Accounting, 33 (5-6), 715-734. https://doi.org/10.1111/j.14685957.2006.00602.x

17. Hribar et al. (2014). A new measure of accounting quality. Review of Accounting Studies, 19, 506-538. https://doi.org/10.1007/s11142-013-9253-8 
18. Haq \& Leghari, (2015). Determinants of audit fee in Pakistan. Research Journal of Finance and Accounting, 6 (9), 176-188.

19. Imhoff, E.A. (2003). Accounting Quality, auditing and corporate Governance. Accounting Horizon supplement, 2(3), 117-128. https://doi.org/10.2308/acch.2003.17.s-1.117

20. Khurana, I., K., \& Raman, K. K. (2004). Litigation Risk and the Financial Reporting Credibility of Big 4 versus Non-Big 4 Audits: Evidence from Anglo American Countries. The Accounting Review, 79 (2), $473-495$. https://doi.org/10.2308/accr.2004.79.2.473

21. Kim, J., Chung, R., \& Firth, M. (2003). Auditor conservatism, asymmetric monitoring and earning management. Contemporary Accounting Research, 20 (2), 323-359. https://doi.org/10.1506/J29K-MRUA0APP-YJ6V

22. Kinney \& Libby (2002). The relation between auditor's fee for non-audit services and earnings management. The Accounting Review, 7(5), 107-114. https://doi.org/10.2308/accr.2002.77.s-1.107

23. Leuz c., Wysocki P. (2008). Economic consequences of financial reporting and disclosure regulation: A review and suggestion for future. Journal of Economic Literature, 7(2), 1-91. https://doi.org/10.2139/ssrn.1105398

24. Lee, J. (2009)), Does size matter in firm performance? Evidence from US public firms. International Journal of the Economics of Business, 16 (2), 189-203. https://doi.org/10.1080/13571510902917400

25. Munro L., Stewart j. (2009). External auditor's reliance on internal audit: the impact of sourcing arrangements and consulting activities. Journal of Accounting \& Finance, 50(2), 371-387. https://doi.org/10.1111/j.1467629X.2009.00322.x

26. Mishra, Raghunandan \& Rama (2005). Do Investor' perceptions vary with the type of non-audit fees? Evidence from auditor ratification voting. Auditing: Journal of Practice \& Theory, 24(2), 9-25. https://doi.org/10.2308/ aud.2005.24.2.9

27. Martinez A. L., Moraes, A. J. (2014). Association between independent auditor fee and firm value: A study of Brazilian Public companies. Journal of Modern Accounting and Auditing, 10(4), 442-450.

28. Niemi. (2005). Audit effort and fees under concentrated client ownership: Evidence from four international audit firms. The international journal of Accounting, 40(4), 303-323. https://doi.org/10.1016/j.inta cc.2005.09.006

29. Paulo, Girao, Carter \& Sousa, (2013). The impact of the adoption of international financial reporting standards on the quality of accounting information of the Brazilian and European public firms. Journal of International Financial Management and Accounting, 30(1), 5-29. https://doi.org/10.2139/ssrn.2270678

30. Raghunandan K., (2003). Non-audit services and shareholder ratification of auditors. Auditing: Journal of Practice \& Theory, 22(1), 155-163. https://doi.org/10.2308/aud.2003.22.1.155

31. Simunic, D. A. 1984. Auditing, consulting, and auditor independence. Journal of Accounting Research, 22 (2), 679-702. https://doi.org/10.2307/2490671

32. Svanström, Tobias (2012). Non-audit services and audit quality: Evidence from private firms. European Accounting Review, 7(1), 1-30.

33. Stanley J.D. (2011) Is the Audit Fee Disclosure a Leading Indicator of Clients' Business Risk? Auditing. Journal of Practice \& Theory, 30(3), 157-179. https://doi.org/10.2308/ajpt-10049

34. Stewart, J., Subramaniam, N. (2010). Internal audit independence and objectivity: emerging research opportunities. Managerial Auditing Journal, 25(4), 328-360. https://doi.org/10.1108/02686901011034162

35. Sufy, F.J., Almbaideen, H. I. M., Al-abaadi, H. M. \& Makhlouf, M. H. (2013). Corporate Governance and its impact on the quality of accounting information in the industrial community shareholding companies listed in Amman financial market-Jordan. International Journal of Humanities and Social Science, 3(5), 184-195.

36. Sami H., Wang J., Zhou H. (2011). Corporate Governance and operating performance of Chinese listed firms. Journal of International Accounting, Auditing \& Taxation, 20(2), 106-114. https://doi.org/10.1016/j.intac caudtax.2011.06.005

37. Tepalagul \& Lin, (2014). Auditor independence and audit quality: A literature review. Journal of Accounting, Auditing \& Finance, 30(1), 101-121. https://doi.org/10.1177/0148558X14544505

38. Ullah, M., Malik., A.M., Zeb, A., Rehman, A. (2019). Mediating Role of Capital Structure between Corporate Governance and Risk. Journal of Managerial Sciences, 13(3), 47-56.

39. Ullah, M., Afghan, N., Afridi, A.S. (2019). Effects of Corporate Governance on Capital Structure and Financial Performance: Empirical Evidence from Listed Cement Corporations in Pakistan. Global Social Sciences Review, 4(3), 273-283. https://doi.org/10.31703/gssr.2019(IV-III).25

40. Ullah, M., Shaikh, M., Channar, P., \& Shaikh, S., (2021). Financial forecasting: an individual perspective. International Journal of Management, 12(3), 60-69.

41. Verrecchia E., Leuz C. (2000). The economic consequences of increased disclosure. Journal of Accounting Research, 38, 91-124. https://doi.org/10.2307/2672910

42. Whisenant, S., Sankaraguruswamy, S. \& Raghunandan, K. (2003). Evidence on the joint determination of audit and non-audit fees. Journal of Accounting Research, 41, 721-44. https://doi.org/10.1111/1475-679X.00121

43. Warfield D., Ashbaugh H. (2003). Audits as a corporate governance mechanism: Evidence from German markets. Journal of international accounting research, 2, 1-21. https://doi.org/10.2308/jiar.2003.2.1.1 
Humanities \& Social Sciences Reviews elSSN: 2395-6518, Vol 9, No 3, 2021, pp 864-876 https://doi.org/10.18510/hssr.2021.9384

44. Yang, T., Zhao, S. (2014). CEO duality and firm performance: Evidence from exogenous shock to the competitive environment. Journal of Banking \& Finance, 49, 534-552. https://doi.org/10.1016/j.jb ankfin.2014.04.008

45. Zhou, J., and Elder, R. (2003). Audit Quality and Earnings management by seasoned equity offering firms. Asia pacific journal of Accounting and Economics, 11(2), 95-120. https://doi.org/10.1080/16081625.2004.10510638 